\title{
Myxiops aphos, new characid genus and species (Characiformes: Characidae) from the rio Lençóis, Bahia, Brazil
}

\author{
Angela M. Zanata and Alberto Akama
}

Myxiops aphos, new genus and species, is described from a river in the eastern portion of Bahia State, Brazil. Myxiops is distinguished from all other characid genera by the combination of the following features: infraorbitals fused in a unique fashion, resulting always in less than six autogenous bones; a single tooth row in the premaxilla; presence of somewhat pedunculate teeth, expanded and compressed distally, with cusps similar in shape and perfectly aligned along distal margin; ventral margin of toothed portion of maxillary curved towards ventral margin of premaxilla and maxillary teeth forming a continuous series with premaxillary teeth; margins of pre- and postzygapophyses with projections anteriorly and posteriorly directed; accumulation of epithelial cells forming globular structures distributed over head and scales; and base of anal fin without scales covering basal portion of unbranched and anterior branched rays. The presence of these features in other characids is discussed.

Myxiops aphos, novo gênero e espécie, é descrita de um rio do leste do Estado da Bahia, Brasil. Myxiops distingue-se de todos os outros gêneros de caracídeos pela seguinte combinação de caracteres: exclusivo modo de fusão dos infraorbitais, resultando em menos de seis ossos autógenos; uma única série de dentes no pré-maxilar; presença de dentes comprimidos com cúspides similares em tamanho e alinhadas ao longo da margem distal dos dentes; margem ventral da porção com dentes do maxilar arqueando-se em direção à margem ventral do pré-maxilar e dentes do maxilar formando um eixo contínuo com os dentes do pré-maxilar; margens das pré- e pós-zigapófises com projeções anterior e posteriormente direcionadas; acúmulo de células epiteliais formando estruturas globulares distribuídas sobre a cabeça e escamas; e base da nadadeira anal sem escamas. A presença destas características em outros caracídeos é discutida.

Key words: freshwater fish, species description, Chapada Diamantina, northeastern Brazil.

\section{Introduction}

Problems concerning the traditional definitions of genera and suprageneric taxa among characids, especially in the subfamilies Cheirodontinae and Tetragonopterinae, have been the subject of a series of discussions (e.g., Eigenmann, 1917:43, 46; Weitzman \& Cruz, 1981:999; Weitzman \& Fink, 1983:344-347; Malabarba, 1998:194; and Lima et al., 2003). Based on multiple character distribution, Malabarba (1998) restricted the Cheirodontinae to 14 genera and shifted 43 genera previously allocated to that subfamily into incertae sedis within the Characidae. The Tetragonopterinae was similarly traditionally treated as a very large subfamily (e.g., Géry, 1977). More recently, in the absence of evidence that Tetragonopterinae represents a monophyletic assemblage
(Weitzman \& Fink, 1983; Weitzman \& Malabarba, 1998) this subfamily has been restricted only to the genus Tetragonopterus (Reis, 2003; Lima et al., 2003). As a consequence of such actions, numerous taxa were listed as incertae sedis in the Characidae by Lima et al. (2003: 106).

The new characid from the rio Paraguaçu of eastern Brazil described herein represents another case of a supra-specific taxon distinguished by a combination of characters from all other characid genus, but of uncertain relationships. This new taxon shares some characters with members of the Cheirodontinae (e.g., one row of pedunculated and multicuspidate premaxillary teeth), but lacks most of the synapomorphies proposed by Malabarba (1998) to define the subfamily. Alternatively, the overall body shape and color pattern of the new form is very similar to those of taxa traditionally allocated

Museu de Zoologia da Universidade de São Paulo, Caixa Postal 42594, 04299-970 São Paulo, SP, Brazil. e-mail: (AMZ) a_zanata@yahoo.com.br; (AA) aakama@ib.usp.br. 


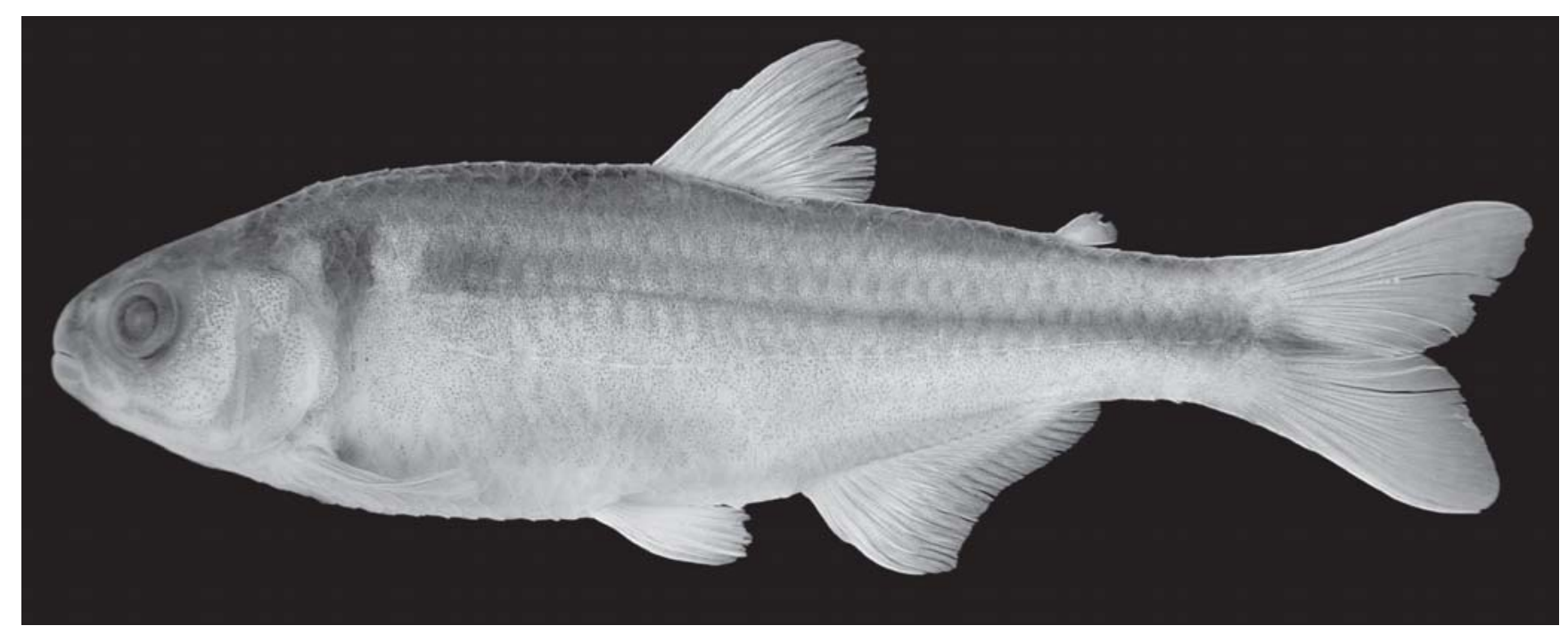

Fig. 1. Myxiops aphos, holotype, MZUSP 81026, 56.0 mm SL; Brazil, Bahia, rio Lençóis.

in the Tetragonopterinae, most notably to Astyanax scabripinnis.

The lack of a hypothesis concerning the phylogenetic relationships of the new species within the Characidae, along with a series of distinctive characters which exclude it from other recognized characid genera lead us to propose a new genus, Myxiops, for the new species.

\section{Materials and Methods}

Counts and measurements presented in table and/or in the text were taken according to Fink \& Weitzman (1974), except for the number of longitudinal scale rows below the lateral line, which were counted from the scale row immediately ventral to the lateral line to the scale row nearest to insertion of the pelvic fin. In Table 1 standard length (SL) is expressed in $\mathrm{mm}$ and all other measurements are expressed as a percent of SL, except subunits of the head that are recorded as percents of the head length. Counts are presented in the species description, followed by frequency in parentheses. Asterisks indicate values for the holotype. Counts of vertebrae, supraneurals and gill-rakers were taken from cleared and stained paratypes (c\&s), following the method discussed by Taylor \& Van Dyke (1985). Vertebral counts include the four centra associated with the Weberian apparatus and have the terminal half centrum and associated vertebral elements (PU1 + U1) counted as one element. Skin fragments of the dorsal portion of the fish head were used for histological analysis. This material was processed in historesin (JB-4 glycolmethacrylate; Polysciences), sectioned at $3 \mu \mathrm{m}$, mounted in glass slides, and stained with hematoxylin/eosin (HE), periodic acid-Schiff's (PAS)/ toluidine blue $0.2 \%$ in pH 7.0 (buffer Mc Ivaine), and in metanil yellow-periodic acid-Schiff's (PAS) hematoxylin (Quintero-Hunter et al., 1991). The examined specimens are deposited in the Museu de Zoologia da Universidade de São Paulo, São Paulo (MZUSP) and Museu de Ciências e Tecnologia, Pontifícia Universidade Católica do Rio Grande do Sul, Porto Alegre (MCP). Osteological terminology is that used by Weitzman (1962), except for the use of anterior ceratohyal that follows Nelson (1969).

\section{Myxiops, new genus}

Type species. Myxiops aphos, by monotypy and present designation.

Diagnosis. Myxiops is a characid genus of relatively small body size (maximum known SL $56.1 \mathrm{~mm}$ ). The following combination of derived features distinguishes Myxiops from all other characid fishes: (1) infraorbitals fused in a unique fashion, resulting in less than six autogenous bones; (2) presence of a single tooth row in the premaxilla; (3) presence of "cheirodontin-like teeth", somewhat pedunculated, expanded and compressed distally, with cusps similar in shape and perfectly aligned along dorsal margin; (4) ventral margin of toothed portion of maxillary curved towards the ventral margin of the premaxilla and maxillary teeth forming a continuous series with premaxillary teeth; (5) margins of pre- and postzygapophyses with projections anteriorly and posteriorly directed; (6) accumulation of epithelial cells forming globular structures distributed over head and scales; and (7) base of anal-fin without scales covering basal portion of unbranched and anterior branched rays.

Etymology. Myxiops from the Greek, myxa for slime, and iops for small fish, in reference to the copious amount of mucous covering the body, which makes the fish very slippery when alive and even for some period after fixation in formalin and storage in alcohol. 


\section{Myxiops aphos, new species}

Figs. 1-2

Holotype. MZUSP 81026, 56.0 mm SL; Brazil, Bahia, Lençóis, rio Lençóis, tributary of rio Paraguaçu, $3 \mathrm{~km}$ upstream of Lençóis city, above Cachoeira do Serrano, 12 34'S 41 ${ }^{\circ} 22^{\prime} \mathrm{W}$. A. Akama, 22 Feb 1995.

Paratypes. MZUSP 81025, 22 specimens, 27.6-56.1 mm SL, 4 c\&s, 26.4- 46.8 mm SL; MCP 35007, 3 specimens, 41.2-48.3 mm SL; same data as holotype.

Diagnosis. As for the genus.

Description. Morphometric data presented in Table 1. Body relatively small, maximum observed standard length $56.1 \mathrm{~mm}$, relatively elongate and transversely rounded, somewhat flattened posterior to terminus of dorsal fin base. Greatest body depth at dorsal-fin origin. Dorsal profile of head distinctly convex from margin of upper lip to region approximately at vertical through anterior nostril, nearly straight from that point to posterior tip of supraoccipital spine. Dorsal profile of body slightly convex from tip of supraoccipital spine to dorsal-fin origin, posteroventrally-inclined along dorsal-fin base, nearly straight from posterior terminus of dorsal-fin base to adipose fin, and slightly convex from posterior part of adipose-fin base to origin of dorsalmost procurrent caudal-fin ray. Ventral profile of head and body distinctly convex on anterior tip of dentary, gently convex from this point to anal-fin origin, straight and posterodorsally inclined along anal-fin base. Ventral profile of caudal peduncle concave.

Head obtusely rounded anteriorly in lateral profile. Contralateral frontals in contact anteriorly; frontal fontanel restricted to posterior portion of frontal bones. Parietal portion of fontanel extending between parietals posteriorly. Supraorbital absent. Jaws equal, mouth terminal, albeit somewhat

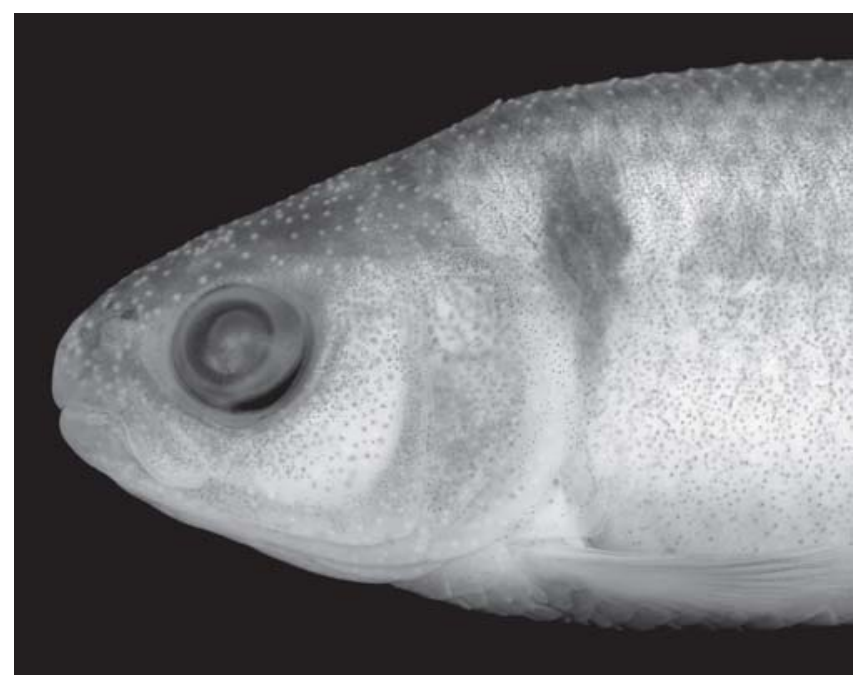

Fig. 2. Myxiops aphos, paratype, MZUSP 81025, male, 45.0 $\mathrm{mm}$ SL; Brazil, Bahia, rio Lençóis. ventrally positioned. Posterior tip of maxilla extending to vertical slightly anterior to or reaching the center of pupil. Gill-rakers 7+1+10 (2) or 6+1+11 (1). Branchiostegal rays 4 (4).

Premaxilla with 5 (26) teeth arranged in single regular tooth row. Teeth pedunculated, expanded, compressed distally, and bearing 5-7 cusps. Cusps compressed, aligned along the distal tooth margin. Central cusp largest. Maxilla with 2 (16) or $3 *(10)$ compressed teeth, each bearing 5 cusps. Three central cusps largest and of approximately same size. Dentary teeth 10 (6), $11(13)$, or $12 *(7)$ arranged in single row with anterior 8-9 teeth largest and pentacuspid, followed posteriorly by 2 tricuspid teeth. Smallest cleared and stained specimen with four posteriormost teeth conical. Dentary teeth similar in shape to premaxillary ones, although slightly curved towards oral cavity. Central cusp largest.

Scales cycloid, circuli absent on exposed area of scales, radii well developed and extending to posterior margin of scales parallel or slightly divergent. Lateral line slightly decurved ventrally, completely pored from supracleithrum to base of caudal fin, with 36* (16), 37 (8) or 38 (2) perforated scales. Scale rows between dorsal-fin origin and lateral line 5 (26). Scale rows between lateral line and pelvic-fin origin $3 *$ (22) or 4 (4). Scales along middorsal line between tip of supraoccipital process and origin of dorsal fin 12 (3), 13 (20) or $14 *(3)$. Horizontal scale rows around caudal peduncle 14 (26).

Dorsal-fin rays ii,8,i (24) or ii,9* (3). Dorsal-fin origin situated at midlength of SL. Base of last dorsal-fin ray located at vertical through anal-fin origin. Adipose-fin origin located posterior to vertical through insertion of last anal-fin ray. Anal-fin rays iv, 14 (2), iv, 15 (10), iv, 16 (7) or iv,17* (7). Analfin origin along vertical through insertion of posteriormost dorsal-fin ray. Pectoral-fin rays i,10 (11) or i,11* (16). Tip of depressed pectoral fin falling short of pelvic-fin insertion. Pelvic-fin rays i,7 (26). Pelvic-fin origin anterior to vertical through dorsal-fin origin. Caudal fin forked, lobes similar in size. Principal caudal-fin rays 10/9 (26). Vertebrae 36 (2). Supraneurals 5 (2) or 6 (1).

Color in alcohol. Examined specimens lack guanine on body or head. Ground color tan. Dark chromatophores concentrated on middorsal surface of head and body. Anterior portion of both dentary and maxilla with dense concentrations of dark chromatophores. Ventral portion of head with scattered, dark chromatophores. Humeral region with two dark blotches, anterior blotch more evident and bordered anteriorly and posteriorly by regions of paler coloration. Anterior blotch vertically elongate, wider dorsally, and situated immediately posterior to opercle. Posterior humeral blotch much less conspicuous, somewhat square-shaped, and formed by dark chromatophores concentrated over three or four scales immediately dorsal to anterior portion of midlateral stripe. Midlateral dark stripe extending from pale area posterior to humeral spot to end of caudal peduncle, more conspicuous and relatively wider posterior to vertical through dorsal-fin origin. Stripe on four middle caudal-fin 
rays extending to tips of rays. All rays with thin line of chromatophores along margins, giving dark contour to each ray. Adipose fin with scattered dark chromatophores. Smaller specimens with overall lighter ground body and fins coloration and with posterior humeral blotch less distinct than in larger individuals.

Sexual dimorphism. None of the specimens have hooks on the fins or any other sexually dimorphic features.

Geographic distribution and habitat notes. The species is known from the rio Lençóis, a tributary of rio Paraguaçu, which is a relatively small, eastern drainage in Bahia State, Brazil (Fig. 3). The type-locality of Myxiops aphos is a shallow, headwater stream, with fast water current over a rocky bottom and margin, and with a small amount of riparian or submerged vegetation. Specimens were collected in small pools $50 \mathrm{~cm}$ deep. The rio Lençóis is a blackwater river such as is characteristic of rivers draining soils that are extremely poor in nutrients and highly acidic (Harley, 1995). Copionodon pecten, a trichomycterid endemic to the rio Paraguaçu drainage (de Pinna, 1992), and one species of loricariid, Neoplecostomus sp., were collected together with Myxiops.

Etymology. The name aphos, from the Greek, meaning dark, obscure, in allusion to the dark color of the water of the rio Lençóis.

Stomach contents. The analysis of the stomach contents of two specimens revealed the presence of filamentous algae, terrestrial vegetal fragments, larvae of the Chironomidae, and unidentified insects fragments.

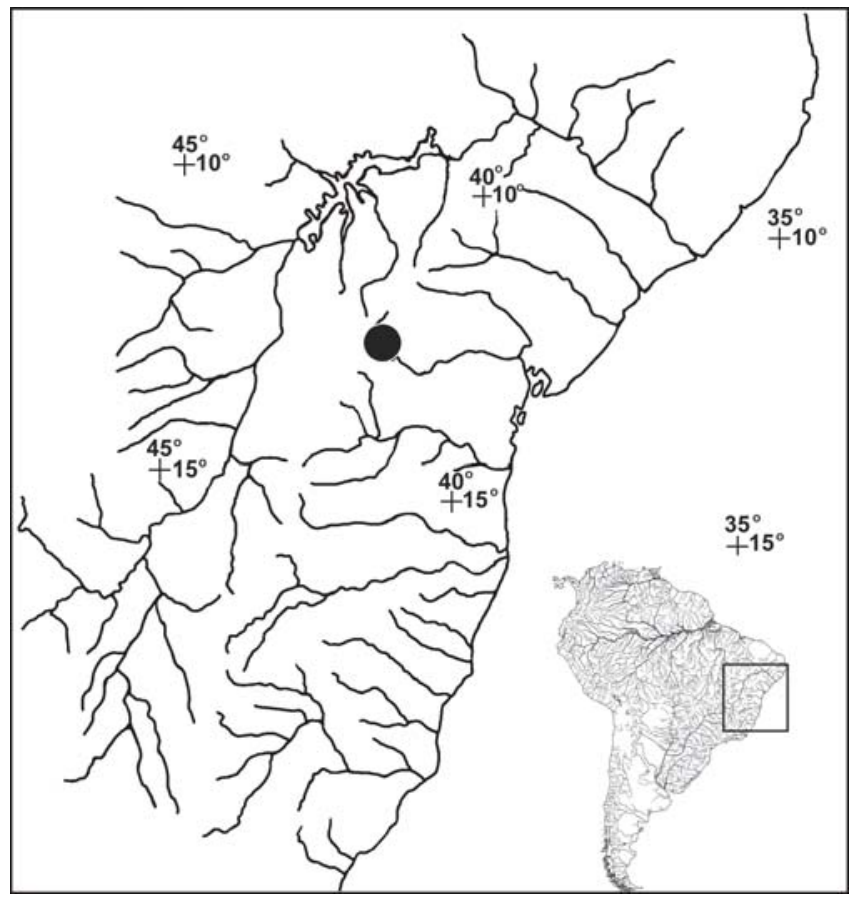

Fig. 3. Northeastern Brazil, showing the approximate position of the type locality of Myxiops aphos.

\section{Discussion}

Myxiops is characterized by a combination of derived features not encountered elsewhere in the Characidae, most notably the variable number of infraorbitals, the "cheirodontin-like" dentition, and the presence of protuberances distributed over head and scales. As mentioned, Myxiops is difficult to allocate even at the subfamily level in Characidae. Myxiops shares similarities with cheirodontines in several aspects of the dentition. These are most likely independent acquisitions since Myxiops does not share all the synapomorphies proposed by Malabarba (1998) to define the group and furthermore possesses a distinct body shape compared to members of Cheirodontinae. Similarly, Myxiops does not correspond to the present definition of Tetragonopterinae (sensu Reis, 2003), since it possesses only one series of compressed and somewhat pedunculated premaxillary teeth.

Among characids, Myxiops differs from Agoniates, Brycon, Bryconops, Clupeacharax, Lignobrycon, Salminus, and Triportheus in various aspects, including the lack of a supraorbital bone. Weitzman \& Malabarba (1998:163) suggested the lack of the supraorbital as a diagnostic character for a monophyletic subunit of the Characidae, including the Aphyocharacinae, Characinae, Cheirodontinae, Glandulocaudinae, Paragoniatinae, Rhoadsiinae, Stethaprioninae, and Tetragonopterinae. Although Myxiops shares the absence of the supraorbital with these taxa, it does not demonstrate the specializations characteristic of any of them.

Preliminary investigations suggest that Myxiops may be related to a various incertae sedis characid taxa, especially those traditionally assigned to the subfamily Tetragonopterinae. The presence of a foramen on the dorsal portion of the anterior ceratohyal was proposed as a potential synapomorphy for at least a component of the Tetragonopterinae by Castro (1984:98) who found this structure in Astyanax, Bryconamericus, Creagrutus, and Piabina. Subsequent phylogenetic analyses (Zanata, 2000; Zanata \& Vari, in press) supported the derived nature of this character, and found that it also occurs in Charax, Roeboexodon, Tetragonopterus, and cheirodontins. Myxiops also possesses such a foramen. We found a similar ceratohyal foramen also in Aphyocharax, Brittanichthys, Ctenobrycon, Deuterodon, Exodon, Hemigrammus, Hollandichthys, Hyphessobrycon, Jupiaba, Knodus, Leptobrycon, Markiana, Mimagoniates, Moenkhausia, Oligosarcus, Paragoniates, Prionobrama, Pristella, Probolodus, Pseudocorynopoma, Rhoadsia, Rhinobrycon, Stichonodon, and Thayeria. Although the possession of this feature can be hypothesized to be a derived character defining a suprageneric group of taxa within Characidae to include Myxiops, the distribution and homology of the feature has yet to be analyzed in an extensive phylogenetic analyses within the family. 


\section{Characters distinguishing Myxiops}

\section{(1) Fusion of infraorbitals.}

The majority of characiforms and most of the characids examined in this study have six infraorbitals that surround the anteroventral through posteroventral margins of the orbit. A reduction in the number of infraorbitals in characiforms has been reported in the literature (e.g. Distichodontidae, Vari, 1979:301; Zanata \& Vari, in press). Within the Characidae, Lucena (1993) reported four infraorbitals in Gnathocharax and five infraorbitals in Acanthocharax, Aphyocharax, Charax, and Roeboides. In his discussion of this character, Lucena (1993:41) pointed out that reduction to five infraorbitals could be due to fusion of infraorbitals 3 and 4 , or 4 and 5, or to the loss of these bones. The presence of a single ossification in the position primitively occupied by infraorbitals 4 and 5 was reported in Heterocharax leptogrammus and H. macrolepis by Toledo Piza (2000:291, 293, fig. 7a). A reduction in the number of autogenous infraorbitals or a fusion of these elements resulting in one large bony element on the position of infraorbital 2 was reported by Weitzman \& Malabarba (1999:14) in species of the cheirodontin genus Spintherobolus. According to the authors, this bony element may consist of fused infraorbitals 1 and 2 .

Myxiops is characterized by the reduction in the number of infraorbitals, which vary from 3 to 5 elements. Each of the four cleared and stained specimens presents a distinct pattern of reduced numbers of these ossifications. The fusions are identified based on the usual position of infraorbitals in a complete series of six elements. One specimen has infraorbitals 1 and 2, and infraorbitals 3, 4, and 5 fused; another specimen has infraorbitals 3,4 , and 5 fused; another specimen has infraorbitals 3 and 4 and infraorbitals 5 and 6 fused to each other. In the last specimen only infraorbitals 4 and 5 are fused. Strikingly, the mode of fusion differs to the two sides of one specimen (Fig. 4). None of the characids used for comparisons shares comparable variation of fusion of infraorbital bones.

\section{(2) Presence of a single premaxillary tooth row.}

The presence of a single premaxillary tooth row was the basis of Eigenmann's (1915) and Géry's (1977) definition of the Cheirodontinae, versus the presence of two or more tooth rows in the premaxilla in other characids. Questions about the utility of these characters in defining supraspecific clades in the Characidae have appeared frequently in the literature (e.g., Weitzman \& Fink, 1983; Malabarba, 1998). Weitzman \& Fink (1983) were the first to explicitly analyze and clearly state these problems when they cladistically diagnosed Paracheirodon, and placed in the genus species with both one and two series of premaxillary teeth. According to Malabarba (1998), Paracheirodon does not belong to the Cheirodontinae and is considered incertae sedis among characids. Malabarba (1998), in his diagnosis of the Cheirodontinae, proposed the reduction in the number of tooth rows in the premaxilla in
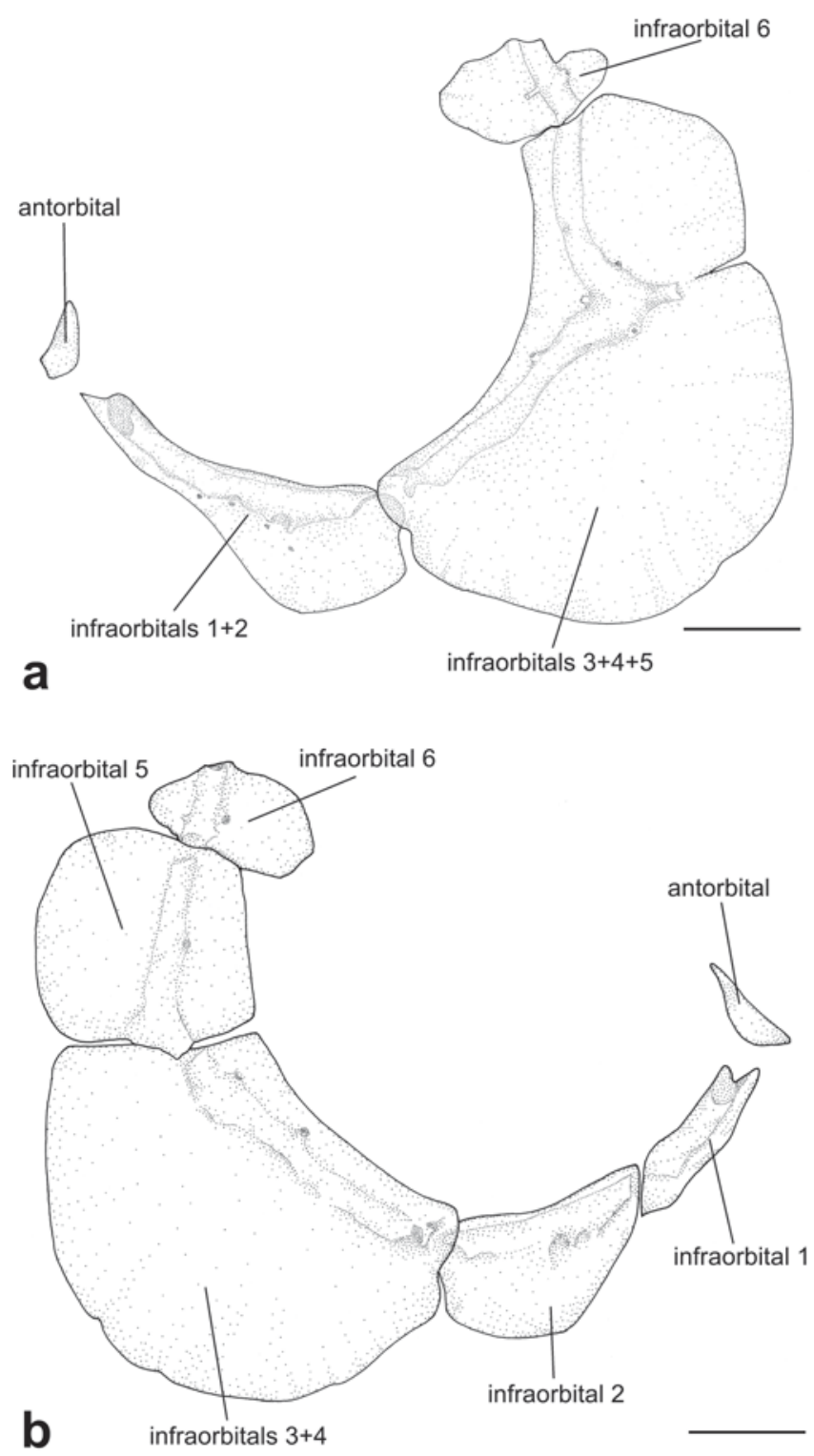

Fig. 4. Infraorbitals and antorbital of Myxiops aphos, MZUSP 81025, $46.4 \mathrm{~mm} \mathrm{SL}$; (a) left side, anterior to left, and (b) right side, anterior to right; lateral view. Scale bar $1 \mathrm{~mm}$.

components of the Characidae to be apomorphic, but not uniquely derived. According to that author, all cheirodontins have a single regular tooth row in the premaxilla and this feature in combination with the alignment and shape of premaxillary teeth is one of the proposed synapomorphies of the subfamily. Elsewhere in the Characidae, a single tooth row in the premaxilla is known in the iguanodectines Piabucus caudomaculatus and P. melanostomus (Cristiano Moreira, pers. comm.) and in various incertae sedis genera (e.g., Aphyocharax, Microschemobrycon, Othonocheirodus, Probolodus).

The five premaxillary teeth of Myxiops are clearly arranged in a single series (Fig.5). Although sharing one row of 
premaxillary teeth with the two species of Paracheirodon and cheirodontines, Myxiops does not share the other synapomorphies defining Paracheirodon or the combination of features diagnosing Cheirodontinae. Similarly, although Myxiops and the two noted species of Piabucus have a single premaxillary tooth row Myxiops lacks the derived features used by Vari (1977) to define the subfamily Iguanodectinae. Finally, none of the incertae sedis characid genera with a single tooth row possesses the combination of derived features characteristic of Myxiops.

(3) Presence of "cheirodontin-like teeth", somewhat pedunculated, expanded and compressed distally, with cusps similar in shape and aligned along the distal border.

Overall the form of the premaxillary dentition of Myxiops resembles that of some members of the Cheirodontinae, with somewhat pedunculated teeth, with the distal portion compressed and laterally expanded. In Myxiops, however, the teeth are somewhat more robust (Fig. 5). As stated in the discussion of the previous character, Myxiops does not share the combination of derived features used by Malabarba (1998) to define the Cheirodontinae.

Myxiops also shares some similarities in the shape of teeth and cusps with Deuterodon and members of the subfamily Iguanodectinae. Myxiops differs from Deuterodon in having a single series of premaxillary teeth and although both genera share some similarities in overall tooth shape they differ in various details of dentition. In Deuterodon the cusps of the inner premaxillary teeth series are arranged in a gentle arch convex towards the exterior of mouth. Myxiops, in contrast, has the premaxillary tooth cusps aligned in a straight line or in a gentle arch facing the oral cavity.

Due to the differences in the number of tooth rows and the arrangement of tooth cusps between Myxiops and Deuterodon, and given the lack of characters supporting a close relationship of these two genera, it is inappropriate to propose the inclusion of the new species described herein in Deuterodon. Myxiops does not share the derived characters proposed by Vari (1977) to define the subfamily Iguanodectinae and the similarities of shape and cusps of teeth observed in these taxa are herein interpreted as independent acquisition.

(4) Ventral margin of toothed portion of maxilla curved towards the ventral margin of the premaxilla and maxillary teeth forming a continuous series with teeth in the premaxilla.

This character was first cited by Lucena \& Lucena (1992:154) as a feature shared by Deuterodon amniculus, $D$. garujo, D. langei, D. rosae, and D. stigmaturus. In their discussion the authors mentioned the presence of this condition also in the cheirodontine Cheirodon terrabae, and in the incertae sedis characids Monotocheirodon pearsoni, Othonocheirodus eigenmanni, and Odontostoechus lethostigmus. More recently, Lucena \& Lucena (2002:118) defined the alignment of the maxillary and premaxillary teeth as a synapomorphy for seven species of Deuterodon. According to the authors, the apomorphic condition within Deuterodon, occurring in D. langei, D. rosae and $D$. stigmaturus, is to have 3 or 4 maxillary teeth aligned to the teeth in the premaxilla. The remaining species of the genus, D. iguape, D. longirostris, D. singularis, and D. supparis, have only the first and rarely the second maxillary teeth aligned to the teeth on the premaxilla. The continuous alignment of the maxillary and premaxillary teeth (synapomorphy number 2 of Lucena \& Lucena, 2002) appears to be directly related with the anteroventral inclination of the ventral margin of the toothed portion of the maxilla (condition described under synapomorphy number 1 of Lucena \& Lucena, 2002). The opposite condition occurring in the remaining characids (Lucena \& Lucena, 2002), and in most of the comparative material examined herein, is a straight ventral margin of the maxilla, forming an angle with the ventral margin of the premaxilla and consequently having the maxillary teeth inclined or perpendicular to the mouth opening.

Myxiops has the maxillary teeth aligned with the teeth on the premaxilla, a condition similar to that observed in Deuterodon iguape, D. longirostris, $D$. singularis, and $D$. supparis. Maxillary teeth continuous with those in premaxilla at some degree also occurs in Hollandichthys multifasciatus. In Myxiops the maxillary teeth are inserted in a relatively curved portion of the ventral margin of maxilla, with at least the first teeth completely aligned and second teeth somewhat aligned with the premaxillary teeth (Fig. 5). The third maxillary tooth, when present, is positioned at an angle with respect to the premaxillary teeth. In the absence of a more encompassing phylogenetic study it is impossible to determine whether these shared attributes are synapomorphic or homoplastic.

\section{(5) Pre- and postzygapophyses with elaborations.}

Most examined characids have zygapophyses without projections or expansions. If present, such projections are relatively weakly-developed and restricted to the postzygapophyses. A distinct condition occurs in Myxiops, wherein the zygapophyses are highly modified with projections from the anterior and posterior borders (Fig. 6). A similar condition, albeit not as developed as in Myxiops, was observed in Astyanax parahybae, A. scabripinnis, and Cheirodon interruptus. Although modifications of the zygapophyses also occur in species of Agoniates, Bryconops, and Serrasalmus, in these taxa such elaborations are represented by posteriorlydirected process of the postzygapophysis fitting between anteriorly-directed processes of the prezygapophysis of the adjacent vertebra. Thus, these processes are correlated with the interlocking system between adjacent vertebrae in the taxa listed above and represents distinct feature from that described in Myxiops.

(6) Protuberances distributed over head and scales.

Myxiops has unusual globular structures externally visible as "white dots" over the fish body (Fig. 2). The external 
appearance of these structures could suggest the presence of glandular tissue, possibly associated with the large amount of mucous over the fish body. Histological examination, however, revealed that these structures represent only an accumulation of epithelial cells. Although a high number of glandular cells are also present in the epidermis of Myxiops they apparently are not associated with the structures described above. The globular structures are scattered throughout the body but are more concentrated over the dorsal portion of the head, infraorbitals, opercles, and lower jaw. On the scales, these structures are located along the posterior border, demarcating its contour. In the majority of the examined specimens of Myxiops, the globular structures occur on most of the scales but are more heavily concentrated on the series of scales above lateral line. Although specimens of Myxiops up to $46.2 \mathrm{~mm} \mathrm{SL}$ always have numerous "white dots", their presence is not constant and are sometimes nearly absent in larger specimens.

The presence of similar epidermal structures identified as breeding tubercles has been reported in various Characiformes including the families Characidae, Lebiasinidae and Parodontidae, where they occur mostly in males (Wiley \& Collette, 1970; Collette, 1977). Although the structures described herein for Myxiops are reminiscent of the breeding tubercles cited above, in Myxiops the accumulation of epithelial cells are more conspicuous in juveniles and occurs both in males and females. This difference in distribution raises questions about the homology of the epidermal structures in Myxiops versus the breeding tubercles present in lebiasinids and parodontids. We consequently do not use the term breeding tubercles for Myxiops at the moment and wait for a more detailed comparative analysis including taxa with this modification.

Within Characidae, protuberances apparently similar to those observed in Myxiops were reported for Bryconamericus cascajalensis by Meek \& Hildebrand (1916: 284), for an unidentified Bryconamericus species from Panama by Fink (1976: 342), and also in two species of Monotocheirodon by Collette (1977: 238). Observations in the present study revealed the presence of such epidermal structures in an undescribed species of Astyanax, from the rio São Francisco drainage, Brazil. Contrary to the condition found in Myxiops, in this species of Astyanax these structures are smaller and not so conspicuous both in external view and through histological preparations. Moreover, presence of protuberances in Astyanax sp. are not constrained by body size, being abundant in the head and dorsal series of scales in the largest specimen examined $(54.5 \mathrm{~mm}$ $\mathrm{SL})$. Also, Astyanax sp. has fewer glandular cells in the epidermis when compared to that of Myxiops. Although sharing concentration of epithelial cells on the epidermis, Astyanax sp. does not share any of the other putatively derived features listed for Myxiops. As mentioned before, the exact homology of the described epidermal structures in the taxa with these modifications is uncertain and depends on future studies.

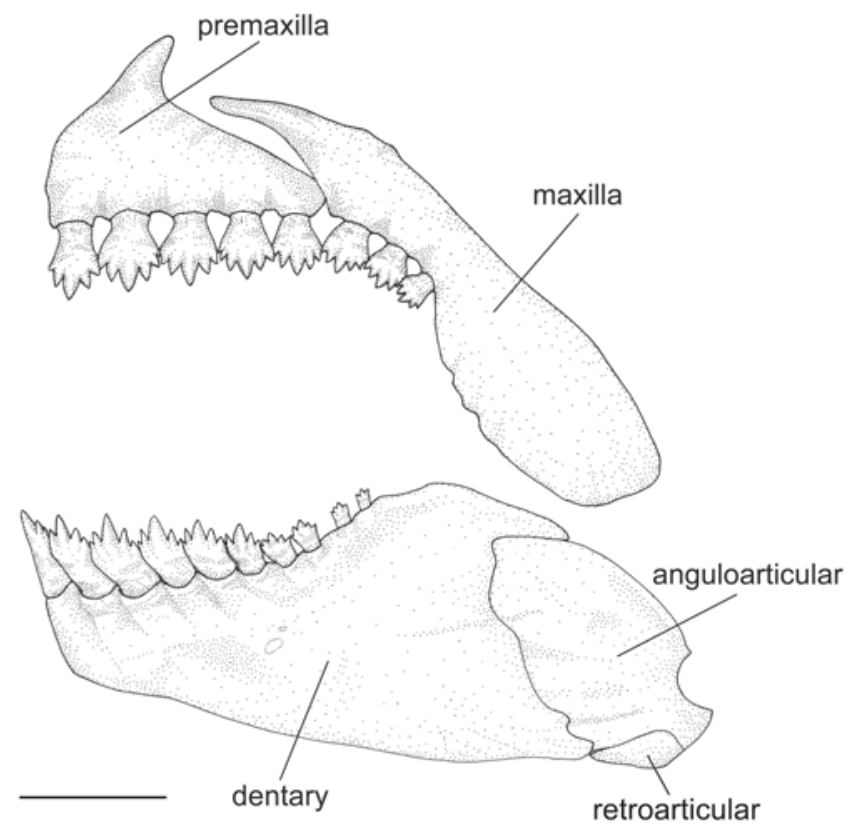

Fig. 5. Upper and lower jaws of Myxiops aphos, MZUSP 81025, $46.4 \mathrm{~mm}$ SL; lateral view, anterior to left. Scale bar $1 \mathrm{~mm}$.

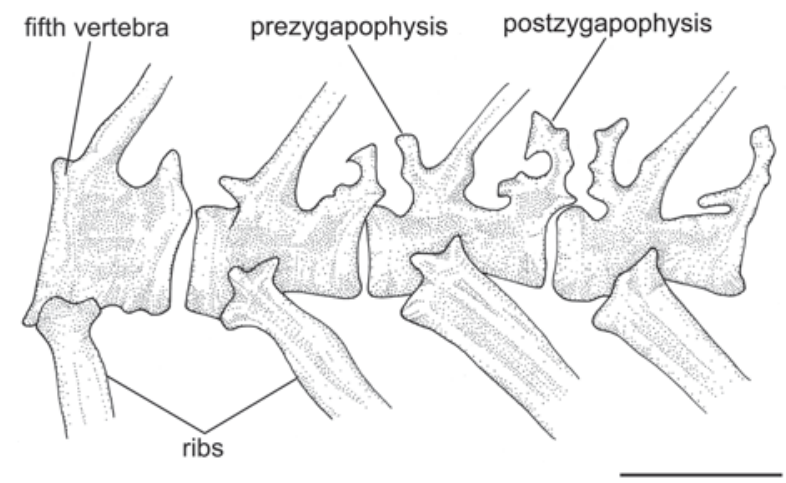

Fig. 6. Vertebrae 5 to 8 showing the form of pre- and postzygapophyses, MZUSP 81025, $46.4 \mathrm{~mm} \mathrm{SL}$; lateral view, anterior to left. Scale bar $1 \mathrm{~mm}$.

\section{(7) Base of anal fin without scales covering basal portion of unbranched and anterior branched rays.}

Most characids possess a sheath of scales extending along the anal-fin base, which are usually smaller than those of adjoining regions of the body, and have their free borders projecting over the proximal portion of the adjacent rays (Malabarba \& Vari, 2000). Rarely is the presence/absence of this sheath of scales cited in species description, except in a few cases (Eigenmann, 1917, 1918, 1921, 1927; Vari \& Siebert, 1990; Malabarba \& Vari, 2000; Malabarba \& Weitzman, 2003) that indicate a considerable variation of this character from having the anal-fin base completely naked, such as in some glandulocaudine and iguanodectine species, to the presence of 3 or 4 longitudinal rows of scales along the anal-fin base in 
Table 1. Morphometric data for Myxiops aphos (MZUSP 81026, 1 ex; MZUSP 81025, 21 ex; MCP 35007, 3 ex).

\begin{tabular}{|c|c|c|c|c|}
\hline Character & Holotype & $\mathbf{N}$ & Range & Mean \\
\hline Standard length (mm) & 56.0 & 26 & $27.6-56.1$ & 44.9 \\
\hline \multicolumn{5}{|c|}{ Percents of standard length } \\
\hline Depth at dorsal-fin origin & 27.9 & 26 & $25.4-29.7$ & 27.9 \\
\hline Snout to dorsal-fin origin & 52.5 & 26 & $50.0-54.8$ & 52.6 \\
\hline Snout to pectoral-fin origin & 23.8 & 26 & $23.1-27.2$ & 24.5 \\
\hline Snout to pelvic-fin origin & 47.5 & 26 & $46.1-50.3$ & 47.3 \\
\hline Snout to anal-fin origin & 64.5 & 26 & $60.1-66.9$ & 63.8 \\
\hline Caudal peduncle depth & 11.1 & 26 & $10.6-12.2$ & 11.3 \\
\hline Pectoral-fin length & 18.6 & 26 & $16.7-19.5$ & 18.3 \\
\hline Pelvic-fin length & 13.2 & 26 & $11.3-14.5$ & 13.1 \\
\hline Dorsal-fin height & 20.0 & 26 & $19.1-22.4$ & 20.4 \\
\hline Anal-fin base length & 20.0 & 26 & $17.0-20.8$ & 19.3 \\
\hline Longest anal-fin ray length & 12.7 & 26 & $10.0-15.9$ & 13.2 \\
\hline $\begin{array}{l}\text { Dorsal-fin origin to caudal } \\
\text { peduncle }\end{array}$ & 50.9 & 26 & $49.1-52.6$ & 50.8 \\
\hline Head length & 25.7 & 26 & $24.6-28.3$ & 25.7 \\
\hline \multicolumn{5}{|c|}{ Percents of head length } \\
\hline Horizontal eye diameter & 25.0 & 26 & $25.0-32.4$ & 27.6 \\
\hline Snout length & 25.0 & 26 & $23.0-27.9$ & 25.3 \\
\hline Least interorbital width & 29.9 & 26 & $28.0-33.9$ & 30.9 \\
\hline Upper jaw length & 36.8 & 26 & $32.7-38.6$ & 36.7 \\
\hline
\end{tabular}

some tetragonopterines (e.g., Gymnocorymbus thayeri, Tetragonopterus argenteus). The most common condition in small characids is the presence of one series of 5-9 scales overlapping the base of the anterior anal-fin rays. Examined specimens of Astyanax scabripinnis have a unique series of 5-6 scales over the base of the anterior anal-fin rays, while in Deuterodon species there are 5 to 9 scales.

In Myxiops, however, anal-fin base is completely naked, without a sheath of scales and not even the ventral portion of the adjacent series of scales covers anal-fin base. Although sharing anal-fin base completely naked with species of Iguanodectes (e.g., I. geisleri, I. rachovii, I. spilurus) and with the glandulocaudin Mimagoniates microlepis, Myxiops does not share the synapomorphies diagnosing the subfamilies Glandulocaudinae or Iguanodectinae. The absence of scales over anal-fin base was considered herein as an independent acquisition in Myxiops and the taxa cited above.

Cited Comparative material. All listed specimens were cleared and counterstained unless indicated as alcohol-preserved material (A) or histological preparation (HP). Agoniates anchovia, MZUSP 20130, 1 ex; Aphyocharax pusillus, MZUSP 30573, 2 ex; Astyanax parahybae, MZUSP 42870, 1 ex; A. parahybae, MZUSP 79667, 5 ex (A); A. scabripinnis, MZUSP 49849, 3 ex (A); Astyanax sp., MZUSP 79652, 21 ex (A), 1 ex (HP); Bryconops alburnoides, MZUSP 34590, 1 ex; Brittanichthys axelrodi, MZUSP 29495, 5 ex; Cheirodon interruptus, MZUSP 18894, 1 ex; Ctenobrycon sp., MZUSP 35532, 2 ex; C. hauxwellianus, MZUSP 26155, 1 ex; Deuterodon rosae, MZUSP 28718, 1 ex; Exodon paradoxus, MZUSP 35937, 1 ex; Hemigrammus unilineatus, MZUSP 38713, 1 ex; Hollandichthys multifasciatus, MZUSP 28841, 1 ex; Hyphessobrycon takasei, MZUSP 29842, 2ex; H. eques,
MZUSP 18764, 2 ex; Iguanodectes geisleri, MZUSP 29614, 150 ex (A); I. rachovii, MCP 22992, 25 ex (A); I. spilurus, MZUSP 45684, 20 ex (A); Jupiaba acanthogaster, MZUSP 41418, 8 ex; J. polylepis, MZUSP 26562, 2 ex; Knodus sp., MZUSP 78863, 2 ex; Leptobrycon sp., MZUSP 29885, 1 ex; Markiana nigripinnis, MZUSP 18850, 1 ex; Mimagoniates microlepis, MZUSP 53763, 3 ex; MZUSP 61455, 10 ex (A); Moenkhausia hemigrammoides, MZUSP 30531, 4 ex; Oligosarcus argenteus, MZUSP 37256, 1 ex; Paragoniates alburnus, MZUSP 26707, 1 ex; Prionobrama cf. filigera, MZUSP 35608, 2 ex; Pristella sp., MZUSP17718, 1 ex; Probolodus heterostomus, MZUSP 7904, 1 ex; MZUSP 35938, 24 ex (A); Pseudocorynopoma doriae, MZUSP 19874, 2 ex; Rhoadsia altipinna, FMNH 93168, 3 ex; Rhinobrycon negrensis, MZUSP 29387, 2 ex; Serrasalmus rhombeus, MZUSP 56425, 1 ex; Stichonodon insignis, MZUSP 6883, 1 ex; Thayeria sp., MZUSP 61955, 2 ex.

\section{Acknowledgments}

The manuscript benefited from comments and suggestions from Naércio Aquino Menezes, Flávio C. T. Lima, Richard P. Vari, and Luiz Malabarba. We thank Lilian Casatti for identifying the fish stomach contents. All osteological drawings were prepared by Kelly Cristina Mautari. We are particularly indebted to Rafael Henrique Nóbrega and Irani Quagio-Grassiotto for their efforts in doing histological sections useful for this study.

\section{Literature Cited}

Castro, R. M. C. 1984. Osteologia e relações filogenéticas de Engraulisoma taeniatum Castro, 1981 (Ostariophysi, Characiforms, Characidae). Unpublished Ms.C. Thesis. Universidade de São Paulo, São Paulo. $156 \mathrm{p}$.

Collette, B. B. 1977. Epidermal breeding tubercles and bony contact organs in fishes. Pp. 225-268 in R. I. C. Spearman (Ed). Comparative Biology of the Skin. Symposia of the Zoological Society, London, 39. Zoological Society of London, London.

Eigenmann, C. H. 1915. The Cheirodontinae, a subfamily of minute characid fishes of South America. Memoirs of the Carnegie Museum, 7(1):1-99.

Eigenmann, C. H. 1917. The American Characidae [Part 1]. Memoirs of the Museum of Comparative Zoology, 43(1):1102.

Eigenmann, C. H. 1918. The American Characidae [Part 2]. Memoirs of the Museum of Comparative Zoology, 43(2):103-208.

Eigenmann, C. H. 1921. The American Characidae [Part 3]. Memoirs of the Museum of Comparative Zoology, 43(3):209-310.

Eigenmann, C. H. 1927. The American Characidae [Part 4]. Memoirs of the Museum of Comparative Zoology, 43(4):311-428. 
Fink, W. L. 1976. A new genus and species of characid fish from the Bayano River basin of Panama (Pisces: Cypriniformes). Proceedings of the Biological Society of Washington, 88(30):331-344.

Fink, W. L. \& S. H. Weitzman. 1974. The so-called Cheirodontin fishes of Central America with descriptions of two new species (Pisces: Characidae). Smithsonian Contributions to Zoology, (172):1-46.

Géry, J. 1977. Characoids of the World. Neptune City, New Jersey, T.F.H. Publications, 672 p.

Harley, R. M. 1995. Introduction. Pp. 1-40. In: B. L. Stannard (Ed.). Flora of the Pico das Almas - Chapada Diamantina, Bahia, Brazil. Richmond, England, Royal Botanical Gardens, Kew, 853p.

Lima, F. C. T., L. R. Malabarba, P. A. Buckup, J. F. Pezzi da Silva, R. P. Vari, A. Harold, R. Benine, O. T. Oyakawa, C. S. Pavanelli, N. A. Menezes, C. A. S. Lucena, M.C. S. L. Malabarba, Z. M. S. Lucena, R. E. Reis, F. Langeani, L. Casatti, V. A. Bertaco, C. Moreira \& P. H. F. Lucinda. 2003. Genera Incertae Sedis in Characidae. Pp. 106-169. In: Reis, R. E, S. O. Kullander \& C. F. Ferraris Jr. (Eds.). Check List of the Freshwater fishes of South and Central America. Porto Alegre, Brazil: Edipucrs, 729p.

Lucena, C. A. S. de. 1993. Estudo filogenético da família Characidae com uma discussão dos grupos naturais propostos (Teleostei, Ostariophysi, Characiformes). Unpublished Ph.D. Dissertation. Universidade de São Paulo, São Paulo, 158 p.

Lucena, C. A. S. de \& Z. M. S. de Lucena. 2002. Redefinição do gênero Deuterodon Eigenmann (Ostariophysi: Characiformes: Characidae). Comunicações do Museu de Ciências e Tecnologia da PUCRS, Porto Alegre, Série Zoologia, 15(1):113-135.

Lucena, Z. M. S. de \& C. A. S. de Lucena. 1992. Revisão das espécies do gênero Deuterodon Eigenmann, 1907 dos sistemas costeiros do sul do Brasil com a descrição de quatro espécies novas (Ostariophysi, Characiformes, Characidae). Comunicações do Museu de Ciências e Tecnologia da PUCRS, Porto Alegre, Série Zoologia, 5(9):123-168.

Malabarba, L. R. 1998. Monophyly of the Cheirodontinae, Characters and Major Clades (Ostariophysi: Characidae). Pp.193-234. In: Malabarba, L. R., R. E. Reis, R. P. Vari, Z. M. Lucena \& C. A. S. Lucena (Eds.). Phylogeny and Classification of Neotropical Fishes. Porto Alegre, Brazil: Edipucrs, 603p.

Malabarba, L. R. \& R. P. Vari. 2000. Caiapobrycon tucurui, a new genus and species of characid from the rio Tocantins basin, Brazil (Characiformes; Characidae). Ichthyological Exploration of Freshwaters, 11(4):315-326.

Malabarba, L. R. \& S. H. Weitzman. 2003. Description of a new genus with six new species from southern Brazil, Uruguay and Argentina, with a discussion of a putative characid clade (Teleostei: Characiformes: Characidae). Comunicações do Museu de Ciências e Tecnologia da PUCRS, Porto Alegre, Série Zoologia, 16(1):67-151.
Meek, S. E. \& S. F. Hildebrand. 1916. The fishes of the fresh waters of Panama. Publications of the Field Museum of Natural History, Zoological Series, 10(15):11-374.

Nelson, G. 1969. Gill arches and the phylogeny of fishes with notes on the classification of the vertebrates. Bulletin of the American Museum of Natural History, 141(4):475-522.

de Pinna, M. C. C. 1992. A new subfamily of Trichomycteridae (Teleostei, Siluriformes), lower loricarioid relationships and a discussion on the impact of additional taxa for phylogenetic analysis. Zoological Journal of the Linnean Society, 106: 175-229.

Quintero-Hunter I., H. Grier \& M. Muscato. 1991. Enhancement of histological detail using metanil yellow as counterstain in periodic acid/Schiff's hematoxylin staining of glycol methacrylate tissue sections. Biotechnology Histochemistry, 66:269-172.

Reis, R. E. 2003. Subfamily Tetragonopterinae. Pp. 212. In: R. E. Reis, S. O. Kullander \& C. F. Ferraris Jr. (Eds.). Check List of the Freshwater fishes of South and Central America. Porto Alegre, Brazil: Edipucrs, 729p.

Taylor, W. R. \& G. C. Van Dyke. 1985. Revised procedures for staining and clearing small fishes and other vertebrates for bone and cartilage. Cybium, 9:107-119.

Toledo-Piza, M. 2000. The Neotropical fish subfamily Cynodontinae (Teleostei: Ostariophysi: Characiformes): A phylogenetic study and a revision of Cynodon and Rhaphiodon. American Museum Novitates, (3286):1-88.

Vari, R. P. 1977. Notes on the characoid subfamily Iguanodectinae, with a description of a new species. American Museum Novitates, (2612):1-6.

Vari, R. P. 1979. Anatomy, relationships and classification of the families Citharinidae and Distichodontidae (Pisces, Characoidea). Bulletin of the British Museum (Natural History), Zoology, 36(5):261-344.

Vari, R. P. \& D. J. Siebert. 1990. A new unusually dimorphic Bryconamericus (Pisces: Ostariophysi: Characidae) from the Peruvian Amazon. Proceedings of the Biological Society of Washington, 103(3):516-524.

Weitzman, S. H. 1962. The osteology of Brycon meeki, a generalized characid fish, with an osteological definition of the family. Stanford Ichthyological Bulletin, 8(1):1-77.

Weitzman, S. H. \& C. A. G. da Cruz. 1981. The South American fish genus Rachoviscus, with a description of a new species (Teleostei, Characidae). Proceedings of the Biological Society of Washington, 93(4):997-1015.

Weitzman, S. H. \& W. L. Fink. 1983. Relationships of the neon tetras, a group of South American freshwater fishes (Teleostei, Characidae), with comments on the phylogeny of New World characiforms. Bulletin of the Museum of Comparative Zoology, 150:339-395.

Weitzman, S. H. \& L. R. Malabarba. 1998. Perspectives about the phylogeny and classification of the Characidae (Teleostei: Characiformes). Pp.161-170. In: Malabarba, L. R., R. E. Reis, R. P. Vari, Z. M. Lucena, \& C. A. S. Lucena (Eds.). Phylogeny and Classification of Neotropical Fishes. Porto Alegre, Brazil: Edipucrs, 603p. 
Weitzman, S. H. \& L. R Malabarba. 1999. Systematics of Spintherobolus (Teleostei: Characidae: Cheirodontinae) from eastern Brazil. Ichthyological Explorations of Freshwaters, 10(1):1-43.

Wiley, M. L. \& B. B. Collette. 1970. Breeding tubercles and contact organs in fishes: their occurrence, structure, and significance. Bulletin of the American Museum of Natural History, 143(3):143-216.

Zanata, A. M. 2000. Estudo das relações filogenéticas do gênero Brycon Müller and Troschel, 1844 (Characidae; Characiformes). Unpublished Ph.D. Dissertation. Universidade de São Paulo, São Paulo. 358 p.
Zanata, A. M. \& R. P. Vari. (in press). The family Alestidae (Ostariophysi, Characiformes): a phylogenetic analysis of a trans-Atlantic clade. Smithsonian Contributions to Zoology.
Received March 2004

Accepted June 2004 